\title{
"Certainly Getting About the World": New Zealanders' Experience of the Middle East as a Place During the Second World War
}

\author{
JOSH KING
}

\begin{abstract}
New Zealand's longest and most important campaign of the Second World War was in the Middle East. When New Zealand's Middle Eastern war is discussed, the focus is usually on combat and the lives of New Zealanders on the battlefield. The limited discussion of life behind the lines is dominated by a picture of racism, drunkenness and debauchery with its focal point in Cairo. This article uses primary sources, including diaries, letters and soldier publications, and focusses on how New Zealanders saw the Middle East as a place, through the lenses of the desert, the city, the Holy Land and the ancient world. An examination of these topics reveals a complex and rich picture of respect and loathing, delight and disgust, wonder and disillusionment. Such a picture shows that the one-dimensional understanding of racism and poor behaviour is an entirely inadequate representation of New Zealanders' Middle Eastern war.
\end{abstract}

On 8 March 1942 Lieutenant Ian Johnston wrote a letter to his parents in Hamilton describing his recent movements in the Middle East. He told them that he was "certainly getting about the world, having in the past week, been in three different countries, namely Egypt, Palestine and Syria. I have also stayed or passed through Ismailia, Jerusalem, Tel Aviv, Haifa, Tiberias and Damascus." "Johnston's quote was not atypical among his Second New Zealand Expeditionary Force (2NZEF) comrades. It hints at the extremely mobile nature of New Zealanders during the Second World War in the Middle East, and the diversity of places they encountered.

New Zealanders began arriving in the Middle East in February 1940 when the First Echelon, 2NZEF sailed up the Suez Canal and began to populate the camp set up for them in the desert at Maadi, 12 miles outside of Cairo. ${ }^{2}$ They were joined by the Third Echelon in October, and the Second Echelon, which had been diverted to England, in early $1941 .^{3}$ Maadi Camp became a slice of New Zealand in the Middle East, complete with bars, rugby pitches, a bakery, an ice cream factory and a movie theatre. For many New Zealanders, Maadi would be their home for several years, and by the end of the war 76,000 of the 140,000 New Zealanders who served overseas had passed through the camp. ${ }^{4}$ From their base in Egypt, the men and women of 2NZEF ranged far and wide across the Middle East, seeing active service in Syria, Libya and Tunisia, and visiting Palestine, Transjordan, Iraq and Iran on leave. They encountered barren deserts and fertile farmland; low-lying plains and lofty mountains; massive cosmopolitan cities and tiny villages. While these countries shared some commonality of language, religion and custom, each presented New Zealanders with a different experience.

This article examines the New Zealand experience of the Middle East as a place during the Second World War. It looks at primary material - chiefly diaries, letters, photographs and contemporary soldier publications - to assess how New Zealanders wrote about different places in the Middle East, what they experienced in those places, and how they contextualised those experiences. It argues that the generally accepted picture of New Zealanders' interaction with the Middle East during the war, characterised by racism, drunkenness and debauchery, is far too simplistic and does not do justice to the diversity of experiences New Zealanders had 
while serving in the region. This article will address the New Zealand experience of the Middle East as a place by breaking it down into a number of discrete ideas: the desert, the city, the Holy Land and the ancient world. While all of these subtopics discuss geographical regions, they are not exclusively geographic, and also discuss place thematically.

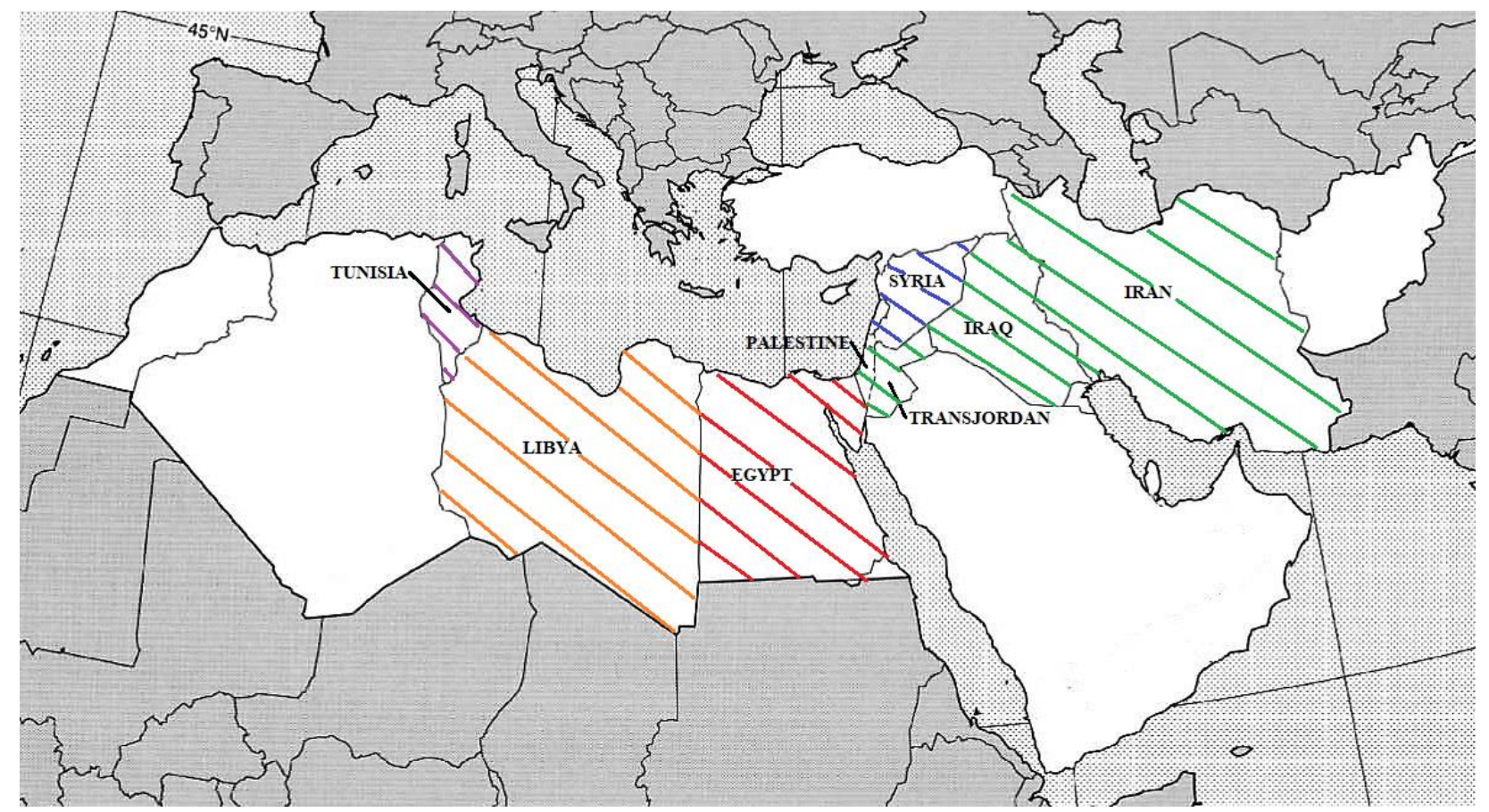

Figure 1. A map detailing all the countries in the Middle East to which New Zealanders went during the Second World War. Dates and, where relevant, division numbers are supplied in the key.

Key $^{5}$

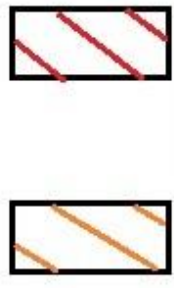

Egypt: 2(NZ) Div. stationed here from 12 February 1940 until 5 October 1943 when Div. left for Italy. New Zealanders reamained in Egypt until Maadi Camp disbanded 26 February 1946

Libya: New Zealanders came in and out of Libya several times as the Allies advanced and retreated: 26 December 1940-28 February 1941; 18 November 1941-2 January 1942; 11 November 1942-1 March 1943

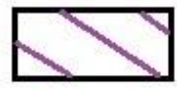

Tunisia: 2(NZ) Div. eventually reached Tunisia after advancing through Egypt and Libya. They were there from 3 March 1943 until their return to Egypt which began on 15 May 1943

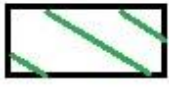

Countries New Zealanders visit on leave: New Zealanders visited Palestine, Transjordan, Iraq and Iran on leave throughout the course of the war.

Syria: 2(NZ) Div. moved to Syria after returning from Libya in January 1942 . There were stationed in the Lebanon Mountains 26 February 1942-19 June 1942 


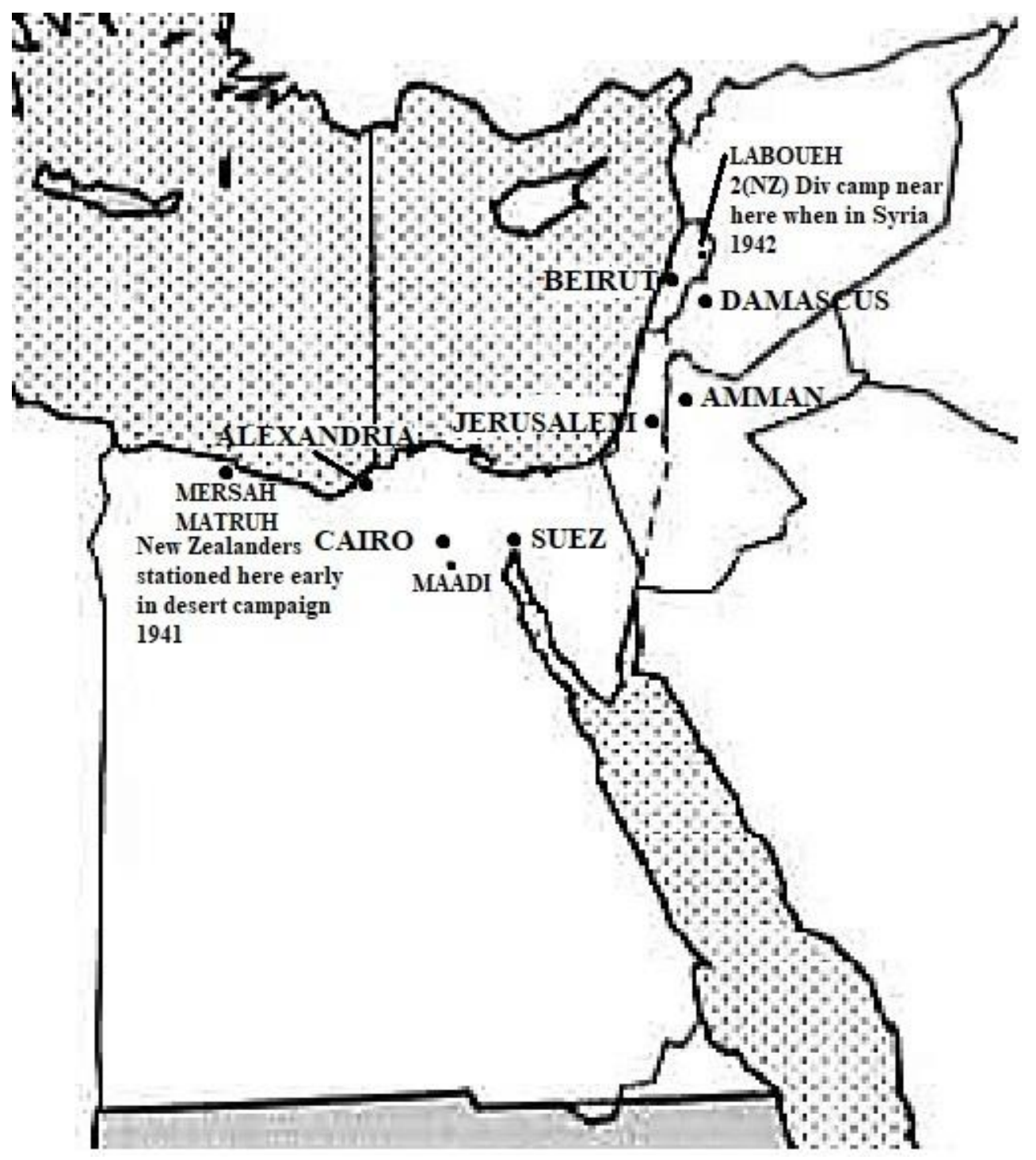

Figure 2. Map showing Egypt, Palestine, Transjordan and Syria. Includes key service and leave locations. ${ }^{6}$

Previous studies of the Second World War in New Zealand have largely focussed on the campaigns and battles fought by 2 (NZ) Division. ${ }^{7}$ This means that, with a few exceptions, the complex off-battlefield history of New Zealand's war remains relatively unexplored. ${ }^{8}$ The gap is especially notable in regard to the Middle Eastern campaign, New Zealand's longest of the war. Ian McGibbon describes the off-battlefield experience in the Middle East as "usually restricted to "booze and bints." venereal disease are brought up again and again. ${ }^{10}$ While I do not argue that alcohol, sex and violence were not features of New Zealanders' interaction with the Middle East, to focus solely on them as the defining features of that interaction is to paint too narrow a picture. The way that New Zealanders experienced and wrote about the Middle East was far more complex, involving ideas of history, religion and racial and cultural difference.

In many respects, this article looks at the men and women of 2NZEF as tourists. Describing his war service, Airman Gerald Craddock (a New Zealander serving with the RAF) labelled it "enforced touristdom," hinting at the military reason for his presence in the Middle East, but also at the role New Zealanders assumed to "get something out of the life." 11 While they were 
in the Middle East to fight a war, New Zealanders managed to do much more besides. They spent their leave in Cairo, Damascus and Jerusalem. They visited the pyramids and the Sphinx, saw Roman ruins, shopped for souvenirs in centuries-old bazaars and took photographs to document it all. It is with these sorts of experiences that this article is primarily concerned.

There is a significant body of literature that examines the soldier-as-tourist, much of it from Australia, beginning with Richard White's influential 1987 article "The Soldier as Tourist."12 As such, the soldier-tourist analogy is not a new one. Indeed, Australian historian Robin Gerster notes that it is "an association originating in Homer's companion stories of the confrontation of the seafaring Greeks with the Trojans at Troy and the perilous remigration of Odysseus." 13 But though not necessarily novel, the soldier-tourist analogy is an interesting one to pursue in light of New Zealand's historiography of the Second World War, so focussed on the combat experience and overarching battle narrative.

As tourists, the New Zealanders of 2NZEF were different from almost all that had come before them. International travel in the nineteenth and early twentieth century was largely confined to a privileged few, with the wealth and leisurely lifestyle to facilitate the time and expense of being a tourist. ${ }^{14}$ The only real touristic forbears that those in 2NZEF had were their First World War counterparts a generation earlier. The mass exodus of people from every stratum of society made soldiers in the First World War "trailblazers," in James E. Kitchen's words. ${ }^{15}$ Because the "enforced touristdom" of the Second World War was again the product of state-funded volunteerism or conscription, the New Zealanders that travelled to the Middle East were a more democratic group than virtually all their predecessors as tourists.

These New Zealand soldier-tourists also demonstrated what some historians have labelled a "vernacular orientalism." 16 This was not the intellectual orientalism of Edward Said, the purview of "poets, novelists, philosophers, political theorist, economists, and imperial administrators." ${ }^{17}$ Rather, according to Eitan Bar-Yosef, it was an orientalism "in the cultural spheres beyond Said's highbrow culture," that "was shared by the educated minority and the masses alike." 18 Kitchen defines vernacular orientalism "as simply expressing an interest in the history and culture of the non-Western world," and New Zealanders in the Second World War certainly expressed such an interest.$^{19}$ They showed (often irrespective of rank, class or gender) that they had imbibed a vernacular orientalism, with all four of the place-lenses discussed in this article already existing, in some form, in New Zealanders' imagined Middle East.

\section{The Desert}

By the Second World War, the desert had long been imbued with special significance in western eyes. With the exception perhaps of the ocean, no other geographical setting was surrounded with such romance. This had not always been the case. Hsu-Ming Teo notes that the desert was "once considered a wasteland populated by wild and savage tribes to be avoided at all costs." ${ }^{20}$ However, as growing European imperial power in the Middle East during the nineteenth century facilitated greater access to the region's "uncharted wastes," a series of romantic tropes began to grow up around the desert.

Many of these tropes centred around the vastness and emptiness of the desert. As romanticism around the desert grew in the nineteenth century, the emptiness that had once rendered it a "wasteland" instead became a positive quality. It provided, in the words of English explorer and orientalist Sir Richard Burton, qualities of "the Indefinite and the Solitude." 21 Vast tracts of uncharted sand became the perfect forum for introspection and self-discovery, free from the clutter and distraction of a rapidly modernising western world. Kathryn Tidrick asserts that, 
from the nineteenth century, the desert provided the traveller with an "ecstatically heightened sense of self." ${ }^{2}$ The journey across the desert was, according to Ellen Turner, "a journey inwards with a focus on the self." 23

But the desert's emptiness not only lent itself to introspection. It also provided a blank canvas for self-projection. The desert became, as Teo notes, "an empty stage for the Romantic ego writ large." 24 A beautiful yet harsh environment, where European travellers could test themselves, projecting personal mastery over the elements. Desert travel required a toughness and self-sufficiency that became, in itself, something to be glorified by romantics. ${ }^{25}$ This opportunity for self-projection created such totemic figures as Wilfrid Scawen Blunt, Gertrude Bell and Lawrence of Arabia, and their exploits only heightened romantic sentiment around the desert.

Underpinning much of the romance around the desert was an amorphous notion of freedom. In the desert, the individual was free to forge their own destiny away from the constraints of modern technology or society. James Canton writes that the desert tantalisingly promised "an emancipation born of the open space which Arabia offers." 26 This notion was well expressed by 1930s explorer Douglas Carruthers, who exclaimed of his travel in the Nafud (in modern Saudi Arabia) that "We were free! A boundless beautiful country lay ahead of us, a rolling desert, with lovely soft contours.... We acknowledged no master, we obeyed no rules-except those most intricate ones of the desert." 27

New Zealanders serving in the Middle East during the Second World War were not immune to the romance of the desert. Many travelled from New Zealand in possession of such romantic ideals as described above. Lieutenant Colonel Frederick Varnham, commander of 19 Battalion, wrote in his diary in November 1940 that he was "pleased to get back to the desert again."28 He had been in Cairo before returning to Bagush in Egypt's Western Desert, and had "had enough of City life." ${ }^{29}$ For Varnham, the desert had "a fascination about it and it is somehow clean and fresh." ${ }^{30}$ Varnham favourably compared the desert to the metropolis, echoing the ideal of the desert as an escape from the constraints of modernity. He praised the cleanliness and freshness of Bagush, no doubt in contrast to the sensory overload of Cairo.

Varnham was not alone in his "fascination" with the desert. Gunner Thomas Birks (known as "Laurie") of 14 Light Anti-Aircraft Regiment wrote to his mother, Mrs. R. L. Birks of Auckland, in January 1942, that "the desert itself has a certain fascination about it I think, very forbidding in some ways, its stark immensity is rather overpowering, and when out in a perfectly flat area without a sign of a break as far as the eye can see, one feels very small and insignificant." ${ }^{31}$ For Birks it seems, the desert's fascination lay in the emptiness that attracted nineteenth- and early twentieth-century travellers, and like them, he was spurred to selfexamination by the scale of the landscape.

However, soldiers like Varnham and Birks were in a distinct minority. If New Zealanders had romantic ideals about the desert, most were quickly disabused of them. Many expressed disappointment that the desert did not live up to their fantasies. Nurse Stephanie Lee of $3 \mathrm{New}$ Zealand General Hospital wrote to her parents that:

the golden desert people think of at home is all wrong. There is very little of that. The real desert is just bare rocky earth. ... Then frequently out of this wilderness there would be a native village hardly visible as it is made out of the very rock around it. . . Not a bit of colour and not even any sign of life except perhaps some scraggy goats, a couple of dirty hens or a scavenging dog. ${ }^{32}$ 
Bombardier Martyn Uren of 4th Field Artillery wrote of the Egyptian desert that "there is not much sandy desert as seen in the films, but one finds mostly the hard-packed earth and rock type of country. Sometimes the land is scrub-covered, but more often desolate of any growth at all." ${ }^{33}$ He was even more scathing of Libya. Far from being romantic, their drive to Tripoli was through "flat featureless desert, dotted everywhere with camel thorn bushes. A more dreary desolate waste would indeed be hard to imagine." 34

As these quotes suggest, New Zealanders encountered a reality that was far more prosaic than the romantic visions of the nineteenth century. They faced extremes of heat and cold, sandstorms, flies, lack of water and living quarters that were often little more than holes in the ground. Added to these discomforts was the fact that the desert was where New Zealanders saw most of their combat, and the fighting and dying brought only further negative associations.

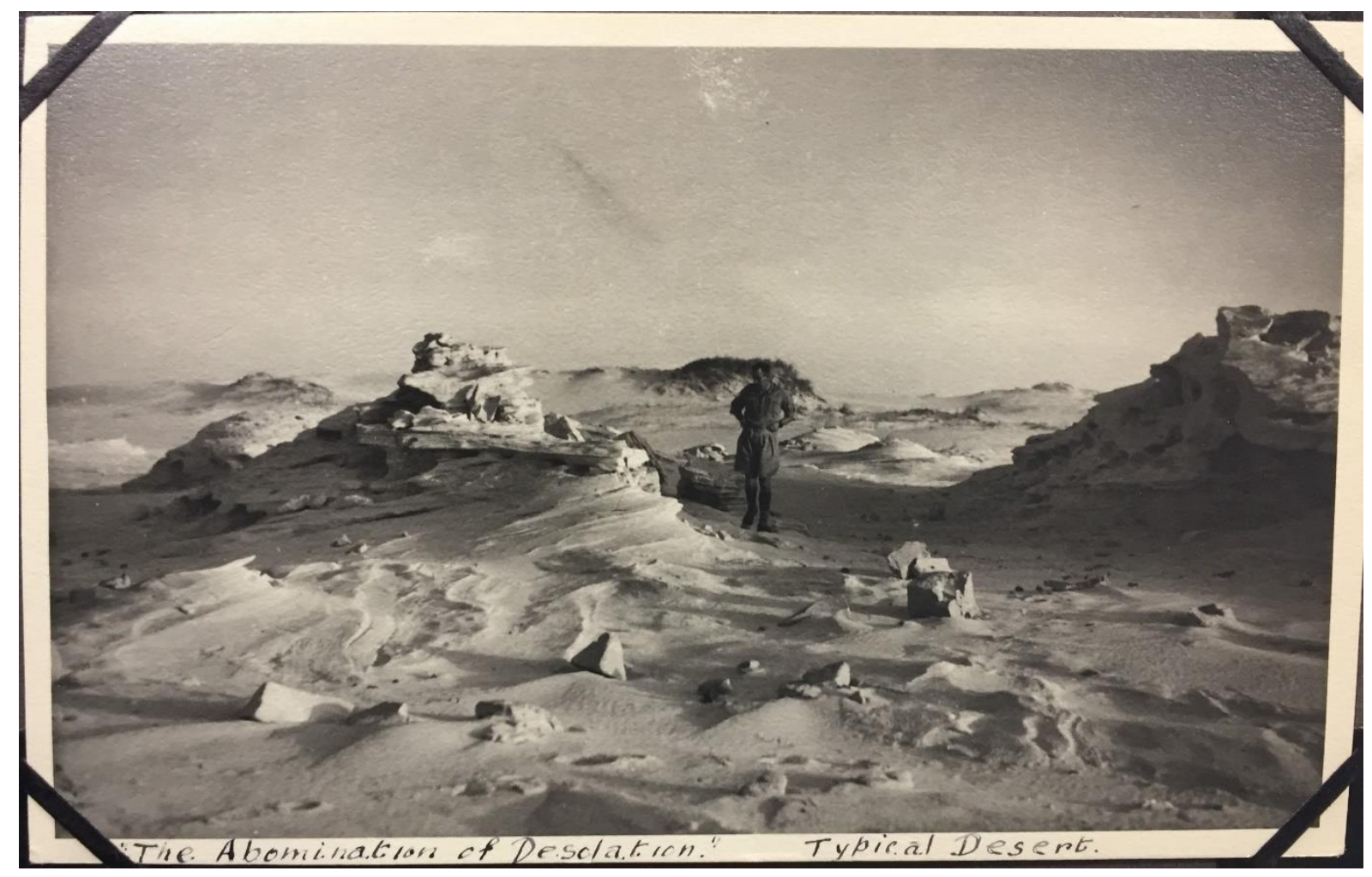

Figure 3. A photo by Captain C Garnett Rands, 25 Battalion, showing "Typical Desert." He labels it "The Abomination of Desolation." 35

The weather in the desert was something that New Zealanders quickly had to adapt to. Moaning about the weather is an age-old soldiers' pastime and discussions of temperature figure prominently in New Zealanders' diaries and letters. An obvious corollary of service in the desert was extreme heat. Private Sydney Hadley wrote in his diary on 24 May 1942 that "the day was a terror temperature up to $115^{\circ}$ at least and not a breath of wind or a bit of shade. Even the lizards would follow us to keep in the shade. Stones too hot to sit on. Only allowed one bottle of water which damn near boiled not much use for quenching a thirst. Just had to sit there with a towel over our face and bake." 36 
Even when some shade was afforded by a vehicle or tent, it made little difference to the stifling heat. Gunner Frederick Mosely wrote to his former comrades at North Head Battery Auckland, that "the past month or so has been pretty hot-once or twice over $120^{\circ}$ in the shade. On the hot days we just lay down on our bunks after lunch and have a siesta and sweat and sweat more." ${ }^{37}$ Private Bassett Carter of 27 Machine Gun Battalion put soldiers' hatred of the desert heat most succinctly in a brief diary entry for 12 May 1940. He simply wrote "Awful dayheat $112^{\circ}$ shade, hot winds and dust storm. Worst day since our arrival." ${ }^{38}$

When the seasons turned in the Middle East, the searing heat was replaced with freezing cold, often accompanied by heavy rain. Some New Zealanders were surprised to encounter such weather in what they had imagined would be a balmy paradise. Gunner Ralph Nicholson wrote in his diary in January 1942 that "the bad weather is making things very unpleasant. It is hard to believe that it can be so cold and wet in the Egyptian desert. Our tents leak like the devil. It has the nasty habit of never leaking in the same spot two nights running." 39 It often took some time for troops to be issued with winter uniforms. Private Walter Young of 5th Field Ambulance wrote in November 1942 that it was "bitterly cold again. We are still in summer shorts and shirts. Have one singlet, a shirt, two pullovers and a greatcoat but still cold. We stayed here all day in rain and mud." $40 \mathrm{He}$ concluded by expressing his frustration with "this bloody desert - you are cooked in the summer and frozen in the winter." 41

Coupled with the temperature was the ever-present sand and dust. Soldiers slept in it, worked in it, fought in it and it filled their clothes, blankets and food. Private Arthur Helm wrote of the morning after his first sandstorm, when stationed at Mersah Matruh in the Western Desert: "Inside the tent sand was everywhere, and it was days later before we were able to get rid of it all. Breakfast was a sorry meal, consisting of porridge and sand, bacon, eggs and sand, tea and sand, and bread and butter and sand." 42 Lieutenant Ian Johnston made similar complaints, noting how personally invasive the sand could be. He wrote to his parents in December 1940 that the sand "gets into your mouth, ears, hair and at meal times you can feel [it] in your food. It would be OK if during the evening it would stop but it goes on all night and on waking in the morning it just looks like a snow fall." 43

However, there was one desert hardship before which all others paled. Flies were a constant blight and many soldiers viewed them as their true foe in desert warfare. Private Rex Griffith wrote home to relatives in Nelson in August 1942 complaining that "the first thing that greeted us on arrival was a swarm of flies. The place is lousy with them. They are our worst enemy. Jerry annoys us some of the time but the flies are here all the time." 44 There was no escaping the flies and their sheer numbers were often beyond comprehension. Laurie Birks recalled his time on the Alamein line, writing in June 1943 that there were "countless millions of [flies], a curse worse than all the rest put together." 45 Walter Young remembered later the flies' "oneness." He wrote that "none was separate from its fellow any more than the wave is separate from the ocean or the tentacle from the octopus. As one fly, one dark and horrible force, guided by one mind, ubiquitous and immensely powerful, it addresses itself to the one task-which was to destroy us body and soul."

In the dry desert environment flies sought moisture. They swarmed around eyes, noses and mouths and covered sweating bodies in a thick black mass. Their propensity for flinging themselves headlong into food and drink earned them the nickname "dive-bombers." Gerald Craddock, a New Zealand bomber crewman with the RAF, wrote that "half a dozen flies zoom through following the mug, as soon as the airman replaces it on the ground it is half filled with a seething swarm of insects." ${ }^{47}$ Laurie Birks continued his letter above, saying that "one of the 
chaps on the other gun said he turned away from his cup of tea to say something to someone, and when looked at it again there were 35 flies in the tea." ${ }^{48}$ Men had to get creative when eating in order to avoid swallowing insects with their bully beef. Martyn Uren often "had to laugh at the sight of . . . some of the boys, running out into the desert against the breeze and cramming food into their mouths as they ran. It was the only way to eat during the day." ${ }^{49}$ Men made traps out of beer bottles or tea mugs covered with handkerchiefs, but their efforts were futile against the flies' sheer numbers.

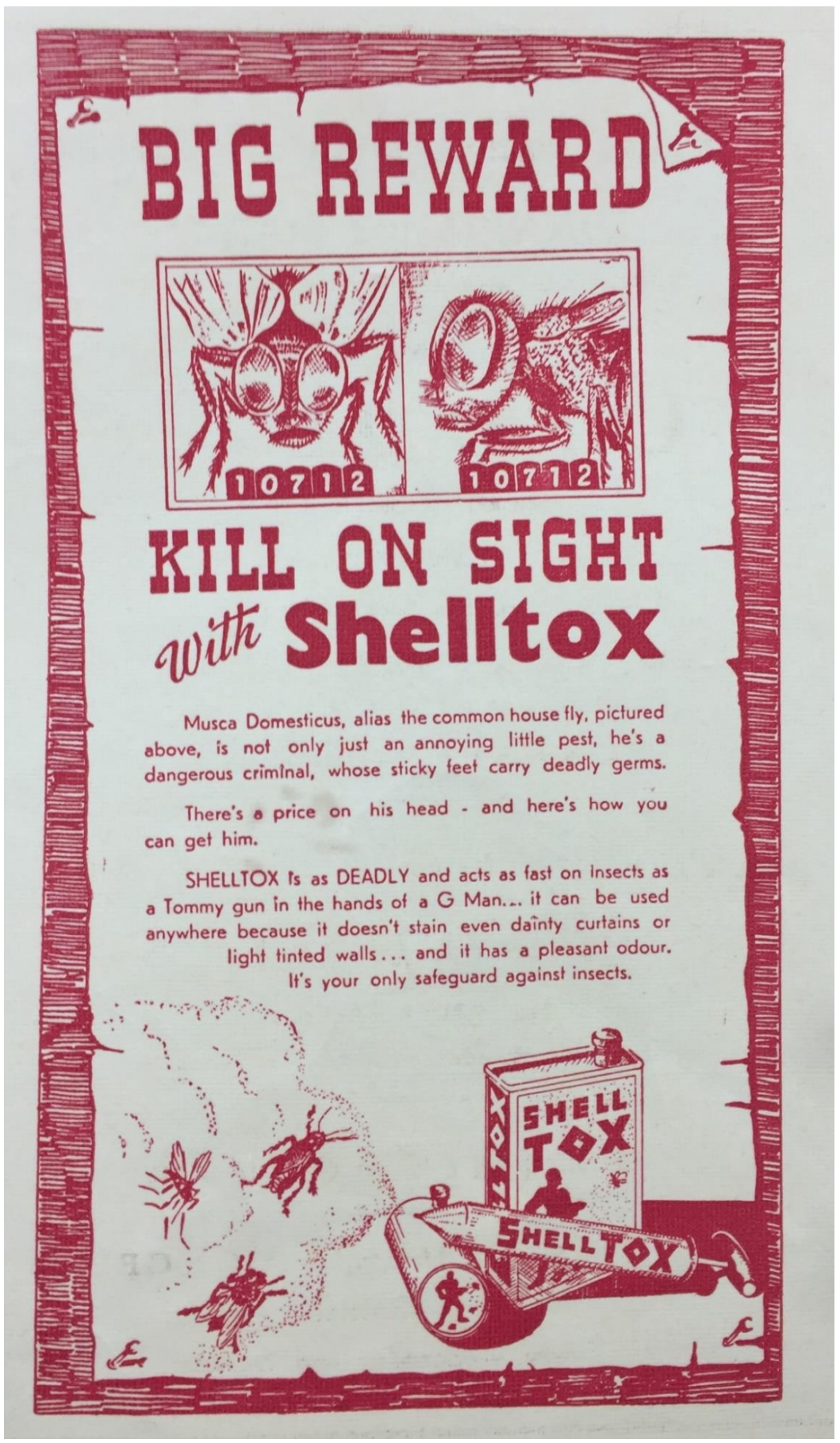

Figure 4. Fly spray ad in a New Zealand Field Ambulance magazine.

Fly spray and home-made traps were used, but provided little relief from flies. ${ }^{50}$ 
Despite the discomfort and deprivations, there were some instances where the desert could move even its most ardent critics. Though most of the terrain New Zealanders encountered was barren and ugly, in the Sinai many finally found their fairy tale desert. Arthur Helm wrote that the Sinai "looked more like a story-book desert than any of the others I had seen. We were travelling through rolling white sandhills, and soon I caught a glimpse of the Mediterranean on the right. A large caravan of camels passed nearby, making their way south, laden with merchandise. . . . It looked like a scene from a 'Sheikh story' of the films." made similar filmic comparisons, stating that the Sinai "seemed to me to be exactly what I had always imagined a real desert would look like. It is the desert of the motion-picture worldthe desert of Beau Geste." 52 Laurie Birks called it "the desert of picture-postcards."

Sunrises and sunsets were often remarked upon with wonderment, even in environments otherwise considered bereft of beauty. Laurie Birks told his mother that "on the subject of sunsets, there have been some magnificent ones here lately. . . They may be partly due to the dust in the air, but anyhow the effects are marvellous, more often than not. Sunrises are the same." 54 Sergeant Harry Dansey of 28 (Maori) Battalion wrote in a May 1944 letter that "sunset is a wonderful time here. .. . The blinding noon day glare fades, the wind drops and the ridges of the escarpment are pale gold and each ... valley fills with purple shadow." 55

However, the Sinai and the sunrises were small exceptions to an otherwise overwhelmingly negative view of the desert. Though there was significant romance surrounding the desert, even in the early twentieth century, the vast majority of New Zealand troops quickly realised the romance little matched the reality. As James Canton states, "the sense of romance which had accompanied many of the adventures of British officers in the earlier Arabian campaign [of WWI] was replaced by a gritty reality in the experiences of thousands of troops sent to the western desert of Egypt." ${ }^{, 56}$

\section{The City}

New Zealander soliders' experience of Middle Eastern cities was more complex than their experience of the desert. There was greater variety in reaction to cities, largely because while there was a lot to loathe, there was also a lot to like about city life. Middle Eastern cities could certainly be overwhelming for New Zealanders, with their size, smells, crowding and dirtiness. However, they were also where New Zealanders spent their leave, providing good food, plentiful drink, shopping and the simple pleasure of a mattress and clean sheets.

For all New Zealanders in the Second World War, exposure to Middle Eastern cities started inauspiciously with Suez. As the disembarkation point for military transports coming up the Red Sea, many New Zealanders had high hopes for this famous port and its equally famous canal. However, what they saw upon arrival was an anticlimax. Bombardier Martyn Uren and his comrades, lying out in the harbour, had "ample opportunity to gain our first impressions of Egypt, and I can say that they were not very favourable ones at first." ${ }^{57}$ He wrote that "for a place so geographically important, Suez is a singularly filthy and unattractive cess-pool. It has absolutely no redeeming feature at all." ${ }^{, 58}$ Private John Hood was similarly unimpressed. Travelling "over what seemed to be an extra large irrigation canal," he "suddenly realised that this was the famous Suez Canal. In the half light it just looked like a big ditch with the sand piled up on either side of it and it was difficult to realise just how important that same ditch had been to the Empire." 59

Fortunately, New Zealanders did not have to spend much time in Suez. Instead, the Middle Eastern city they became most familiar with was Cairo. With Maadi Camp (New Zealand's 
Egyptian base) located in the desert just outside Cairo, this city was the most common leave site for New Zealanders. While they would travel to a myriad of cities over the course of the war, Cairo dominated New Zealanders' urban experience of the region. Upon first arrival, Cairo certainly presented a culture shock. Its sheer size was hard for New Zealanders to comprehend, and Private Bassett Carter noted with awe upon his arrival that the "Cairo population equals that of the whole of NZ." ${ }^{60}$ To many, it seemed that the whole population was there to greet them when they alighted at Cairo's train station. Official historian J. B. McKinney writes that "outside Bab-el-Louk station [New Zealanders] were besieged by bootblack boys trying to earn a few piastres by applying doubtful boot-polish, by unprepossessing pedlars in nightgown-like galabiehs, by gharry drivers seeking a fare in their cabs drawn by feeble-looking horses." ${ }^{61}$ Private Desmond ("Des") Davis summed it all up by noting that "Cairo just swarms." 62

The city has commonly been understood in New Zealand as a backdrop for soldiers' behaviour. As such, it is the behaviour of soldiers while in Cairo that has come to dominate our understanding of the city, both in the First and Second World Wars. The city is usually seen as a passive environment that soldiers acted in, rather than a place that acted on soldiers as well. ${ }^{63}$ Soldiers' behaviour is an important part of the picture but there was also something about the urban environment that engendered particular types of behaviour that rarely happened elsewhere. Cairo was primarily a site of leave and as such transition from camp life to city life represented a release from military discipline. There was a certain permissiveness inherent in the urban landscape of Cairo where, away from active duty, soldiers felt they could "let their hair down." The stereotypical image of the New Zealander on leave in Cairo is one of debauchery and larrikinism, and there were certainly many New Zealanders that conformed to this stereotype. Violence, thieving and property destruction were recurring problems. Gunner Ralph Nicholson's diary features several colourful stories of leave in Cairo. One night in October 1941 he and his comrades "went on the spree," and "Bones, Eric and I went round the streets lassoing wogs. Also swiped a couple of chairs and several trees. It sure was a wild night." 64 In January 1942, Nicholson's comrade "Alf Hey put on a good show in the bar, running up and down the counter and along the shelves at the back. He tore a lamp off the wall and amused himself cranking up the cash register. The barman gave him a free beer to leave it alone." ${ }^{\prime 65}$ Men would frequently get into fights: with each other, with the local population and with other nations' troops. Lieutenant James Barclay remembered that "it didn't take much to ignite a situation in Cairo. . . It was easier to get into a fight than to avoid one. . . It only took one cross word and you could be in a fight that involved fifty people in no time at all."66

The city also meant easy access to prostitution, and New Zealanders often visited Cairo's brothel district, the Wagh El Birket, or "Berka." Reactions to the Berka differed. New Zealand writings show a mix of moral opprobrium and fascination with the open and licensed prostitution they found there. Sapper William Pearson, on his first Cairo leave in March 1941, noted that "all hands proceed to Berka area. A wow of a place. Saw the famous Tiger Lil. Also one of the girls having a bath. . . . A real eye opener this place to civilised people. No shame among these girls of all kinds and nationalities. Some great sights around here." 67 While Pearson stressed that he did not partake in the pleasures on offer, the fascination in his description of the Berka is plain to see. At the other end of the spectrum, Private Francis Jackson wrote that "every soldier in Egypt has heard of the Berker [sic]. The street, and the filthy houses in it, has a revolting, unclean atmosphere, the sort of thing that goes against the grain for the boys who are used to the clean surroundings of homes in New Zealand."68 Despite Sapper Reginald De Grave's statement that "any soldier who served in Egypt and claims- 
hand on heart- - he never patronised a brothel is a liar," it seems that many New Zealanders, like Francis Jackson, found the Berka distasteful. ${ }^{69}$

The Berka became a locus for much of the poor behaviour exhibited by New Zealanders in Cairo. As soldiers frequently drank there, and as it was constantly patrolled by British Military Police ("red caps"), fighting was rife. Perpetual troublemaker Ralph Nicholson wrote in February 1942 that "there was a bit of a brawl up the Birkett [sic] last night. The red caps tried to break up a two up school [a form of gambling]. That started it. The crowd, mostly NZ'ers got stuck into the MP's. They called out re-inforcements and there were about a hundred all told but they got chopped up." ${ }^{70}$ More worryingly for army command, the Berka also put many soldiers out of action with venereal disease, or VD. Many New Zealand troops had lax attitudes towards prophylactic use, as men falsely assumed the licensed prostitutes in the Berka would be "clean." This led to VD rates that, while not astronomical, were more than double the civilian rate back in New Zealand. ${ }^{72}$ By February 1945, 2NZEF had suffered 4000 VD casualties which, as John McLeod notes, "constituted a loss as heavy as the battle casualties of a campaign." ${ }^{, 73}$ Ultimately, the Berka proved too much of a headache for military authorities, and was placed out of bounds in August 1942. ${ }^{74}$ Not that this stopped soldiers going there. For many New Zealanders, the Berka provided exactly what they wanted on leave-in the coarse but succinct words of Driver Anthony Madden, "a feed, a fuck, and a fight. But not necessarily in that order." 75

Alcohol was a key contributor to New Zealand misbehaviour in Cairo (and in other Middle Eastern cities). While men had limited access to beer in camp or in the field, when in Cairo Stella (the "local onion water" according to Reginald De Grave) was available cheaply and in large quantities. ${ }^{76}$ Captain Bruce Robertson wrote in 1942 that "our fellows consumed [beer] by the gallon with of course the usual result, noise and fights and general upheavals. They were a constant nuisance to us, which was always the case when there was drink about." ${ }^{, 77}$ Robertson wrote this at Aleppo in Syria, but it applies equally well to Cairo or any other Middle Eastern city. Private Laurie Birks told his mother that the men were drinking so much beer in Egypt that "the local breweries are working continuously at high pressure, and we're told can't fully supply civilian demands." disgusted by officers' tacit acceptance of it. Birks wrote, of a speech given by his commanding officer, that "he didn't say a word in condemnation of drinking, for one reason I guess because most of the officers do a fair bit of it themselves, not exactly moderately either. . . In any case it would have been a waste of breath to say anything about it, the chaps won't be denied it when it's to be had, and even appeals to restrain their drinking don't seem to have much effect.",79 


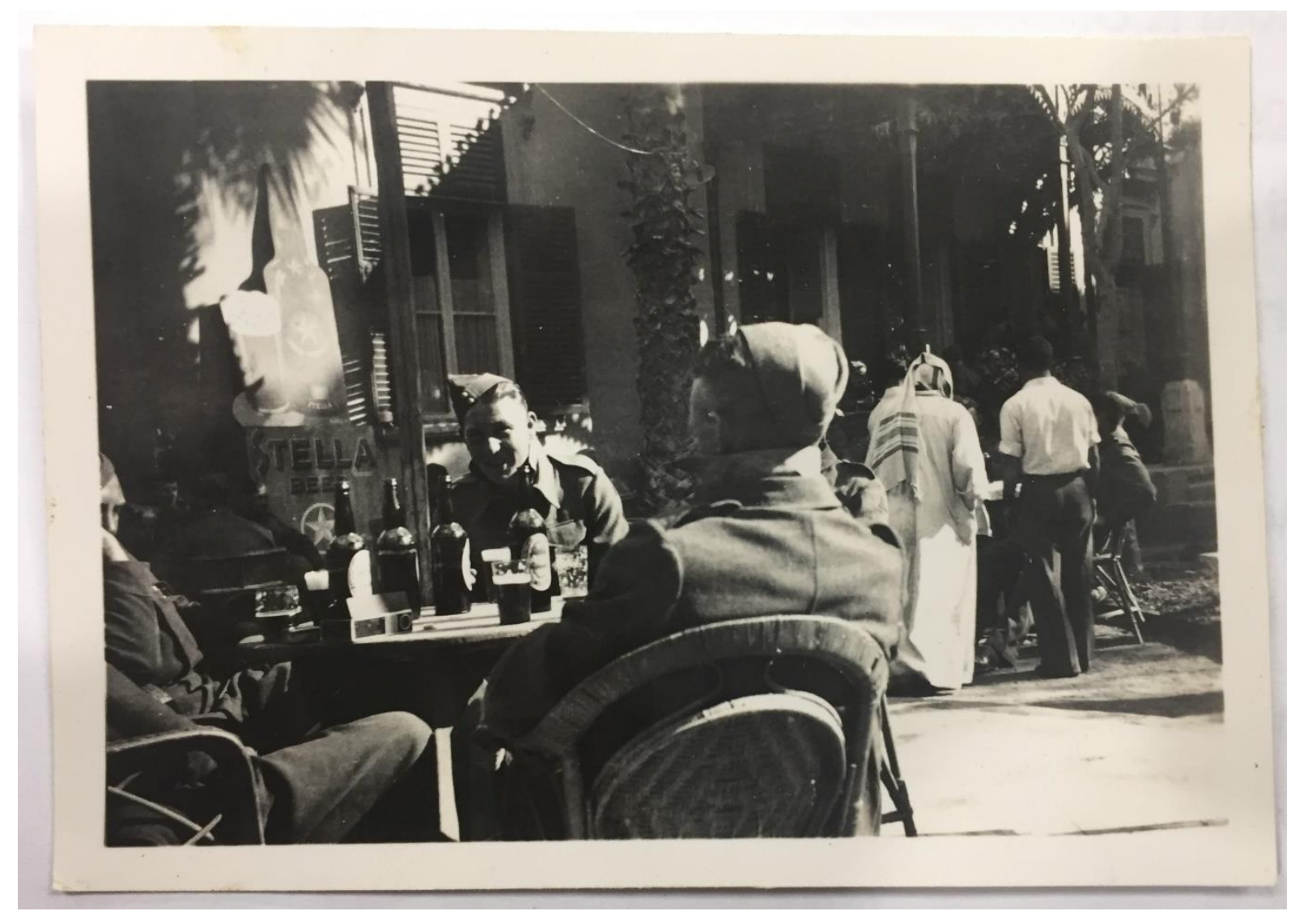

Figure 5. New Zealanders in Cairo.

Note the Stella beer on the table and the large Stella sign in the background. ${ }^{80}$

Many officers were willing to overlook heavy drinking among their men, provided they performed well in combat. Mark Johnston notes this phenomenon among Australian officers, who were sympathetic to their men letting off steam, given the possibility of death or wounding in combat. ${ }^{81}$ Regardless of the accepting attitude of officers, alcohol was the root cause of much of the violence and debauchery associated with the New Zealand experience of Cairo in the Second World War.

Despite this evidence it seems that unruly behaviour in Cairo was confined to a small, though still apparent, minority. ${ }^{82}$ Most New Zealanders were able to enjoy their leave in the city in a more restrained manner, playing the role of tourist much like any civilian traveller would. Cairo had much to offer the open-minded soldier beyond drink, sex and brawling. Accounts of days spent seeing the sights, enjoying a few refreshments and then returning to camp are far more common than accounts of drunken revels. Bombardier Martyn Uren perhaps summed up the typical Cairo leave best in a passage that is worth quoting in full:

Leave ... for myself and whoever happened to accompany me, usually took something like the following form:- a hot bath, shave, haircut and shampoo to start the day with, a good meal of several courses, innumerable cups of coffee or iced drinks according to the season of the year, a look round perhaps to the Zoo, the Citadel, a mosque or the Pyramids for a couple of hours, another large meal, some shopping, a cinema, supper, and home in a gharri to the station. This entire procedure was a ritual with me, and now, three years later, I still do the same things. ${ }^{83}$ 
Unsurprisingly, given its opportunities for rest and relaxation, many New Zealanders grew fond of Cairo. Uren noted, after returning from Greece, that "gradually, almost imperceptibly, I began to acquire a liking for Cairo. ... Perhaps it is because one feels like enjoying comfort, quiet and rest after an action - for I began to know Cairo pretty well about this time, and knew just where these essential conditions could be found." 84 Private Walter Young appreciated "all the goodies this Cosmopolitan city has to offer," and the 24 Battalion magazine Bab el Look labelled Cairo "polyglot, expensive but intensely interesting and very, very educational." ${ }^{85}$ Nevertheless, this attitude was not universal, and many New Zealanders described Cairo in similarly condescending terms as Suez. Private Des Davis called Cairo "a city of the lowest and degenerate type." ${ }^{\prime 6}$ Gunner Thomas Toll wrote that he had "been in Cairo on leave a couple of times but I don't think much of the place. . . . It's a pretty dirty sort of a town and about $3 / 4$ of it is out of bounds to troops." ${ }^{\prime 77}$ For Private Arthur Moore, what stood out was the "filth, stink and squalor." $" 88$

This dichotomy became the pattern for New Zealand reactions to most cities throughout the Middle East. No matter the city, some soldiers would look favourably on the history and shopping, others would dwell negatively on the dirt and smell. One soldier would speak reverently of Damascus as "the oldest city in the world," while another would describe it as "very dirty and wholly native." ${ }^{89}$ In Baghdad, one man would "catch a glimpse of the Arabian Nights," another would see only "a collection of hovels" in "just another Wog town." 90 Thus, we can see that the New Zealand experience of Middle Eastern cities was far more varied than that of the desert. Reactions sat on a spectrum from scathing to favourable, and while a significant minority were interested in causing a scene, most were willing to enjoy the city's attractions quietly and open-mindedly.

\section{The Holy Land}

The Middle East was the birthplace of Christianity. Even by the Second World War, Palestine and Syria (which included Lebanon) were still referred to as the Holy Land. New Zealanders experienced the Holy Land during the war on two levels. Firstly, they experienced it as a geographical place - another of the many environments they found themselves in over the course of the war. Secondly, and perhaps more significantly, they experienced it as an ideaone that was intimately tied to religion. Whether religious or not, New Zealanders could not avoid engaging with religiosity and religious history. Religion featured, to a greater or lesser extent, in all accounts of service or leave in the Holy Land.

Geographically, the Holy Land came in for comment as soon as troops crossed the border into Palestine. This comment was overwhelmingly positive, as New Zealanders contrasted the fertile fields with the barren deserts of Egypt. Private Sydney Hadley wrote on 1 March 1942 that he "crossed the Egypt-Palestine border at 11am and from then on the country became greener and more inviting. It was a great change from the desert which is practically all we had seen for 4 1/2 months. Green low hills very much like N[orth] C[anterbury]." 91 Sergeant George Newton made a similar comparison to home, writing a month after Hadley that "on Monday we went across Palestine and Trans Jordan and being spring it looked just like home, barley and wheat seemed to be the main crops and it is strange to come out of the desert into the green countryside again." 92 Travelling by train or truck, New Zealanders passed miles of irrigated farmland and colourful citrus orchards. Many found it so beautiful that they were reluctant to return to Maadi. Private John Hood wrote on return to Egypt that he "came out to camp in the afternoon and I must say it did not look a very pleasant prospect after the pleasant green fields, orchards and hills of . . . Palestine." 93 
Syria was viewed equally favourably. Encamped in the Lebanon Mountains, 2 New Zealand Division was stationed in Syria for several months in early 1942. Again, the striking natural beauty contrasted favourably with Egypt. Nurse Stephanie Lee, in Beirut with 3NZGH, wrote "we just cannot get over the lovely views up here. After the flatness of Egypt I suppose we notice it more, but really it is such a beautiful country and we all adore it." 94 Private Arthur Helm painted a particularly picturesque image of the mountains, writing that "after coming from the heat of Egypt we found the air of the mountains was delightful, and we drew it into our lungs in great deep breaths. When we reached the summit we asked the driver to stop at the first café, and soon we were sitting in a cool arbour of grapevines, with a fountain playing in the middle, drinking a bottle of wine and eating grapes which had been picked from the vines growing overhead." 95 Gunner Frederick Robbie also contrasted Syria with Egypt, writing that "we are all enjoying the change immensely," and noting that they had even been on "a skiing trip into the hills." 96 The fact that New Zealanders did not have to fight in Syria, and instead were able to ski or drink wine, certainly furthered their liking for the country. Part of the reason they were stationed there at all was to rest and relax after the Division's mauling in Greece, Crete and the early Egyptian battles of 1941.

However, though geography figured prominently, it was religion that dominated New Zealand accounts of Palestine. Many earnestly and unironically used the terms Holy Land or Promised Land to refer to Palestine. ${ }^{97}$ Still more characterised travel there as a pilgrimage, reflecting a growing acceptance among Protestants, increasing since the nineteenth century, of pilgrimage. ${ }^{98}$ We must remember that New Zealanders, even during the Second World War, still came from a society in which Christianity played an important role. Though church attendance had been dropping in the early decades of the twentieth century, the percentage of the population who identified as having no religion in the 1936 census was only 0.3 percent. ${ }^{99}$ Sunday school attendance remained high, and historian Christine Weir states that "from the perspective of the early 21 st century, it is easy to underestimate the scale of the interwar Sunday school movement." 100 In the first decades of the twentieth century, as many as 75 percent of New Zealand children aged five to fifteen were enrolled in Sunday school, and these numbers would not begin to decline until the 1950s and 1960s. ${ }^{101}$ This meant that a large proportion of the Second World War generation had some formal exposure to Christianity, and even when they did not, most still considered themselves to belong to the Christian faith. Military service furthered exposure to Christianity through compulsory church parades and the fact that, unlike during the First World War, chaplains were attached to 2NZEF units. ${ }^{102}$ Chaplains, embedded with the troops, conducted ecumenical services "where barriers of denomination or race were temporarily removed." 103 Many soldiers who were not otherwise churchgoers found these nondenominational services appealing, and received their first formal exposure to Christianity in the very lands being discussed in their chaplains' sermons.

Many New Zealanders were filled with reverence for the religious sites they encountered in the Holy Land. They visited Jerusalem, Nazareth and Bethlehem and gazed upon the Mount of Olives, the Sea of Galilee and the Plain of Esdraelon-all places with evocative Biblical associations. Many felt they were walking in Jesus' footsteps, as Private Francis Jackson noted on visiting the Mount of Olives, writing that "it's a rather frightening feeling to think you may now be treading on the same ground as did Christ, or perhaps one of His disciples." 104 Lieutenant Ian Smith was equally aware of Christ's presence at the Sea of Galilee, which "transported me ... back two thousand years to the fishermen of the lake and their Master."105 These associations reached their apogee at the Via Dolorosa in Jerusalem - the route Jesus took to his crucifixion - of which Private Arthur Helm eloquently wrote that "a vivid picture of the scene rose before me. I could hear the roar that greeted Jesus as He left the Praetorium. I could 
see the narrow way thronged with fanatical Jews looking on the simple Galilean who had presumed to say that if their beautiful temple was destroyed He could rebuild it in three days." ${ }^{106}$ All of these observations reflect a phenomenon noted by religious historian Kerrie Handasyde, that "accounts of travel to the Holy Land are interrupted again and again with the arresting thought that 'here' the sacred may be glimpsed, 'here' proof may be had, and 'here' (rather than elsewhere) Jesus' 'reality' may be more personally felt." "107 For many New Zealanders, travel in Palestine provided a physical manifestation of places or concepts that had previously been only imagined.

Not all New Zealanders were so overawed. Many felt disappointed or disillusioned by what they saw in the Holy Land, especially when it did not match their preconceptions. As Brian Yothers states, travel to the Holy Land represented "an ineluctable tension between what is expected and what is found," and this was certainly the case for New Zealanders. ${ }^{108}$ Often, not coming from a Catholic or Orthodox background, New Zealanders were bewildered by the elaborate shrines and churches they found at important Biblical sites. ${ }^{109}$ Private Roger Smith wrote that "in the Church of the Holy Sepulchre . . . I felt at a disadvantage to my Catholic companions." 110 The Church, "all gleaming in a semi-barbaric display, bore extravagant testimony to the bounty of their faith. I was left in utter bewilderment. Where was the stark hill of the Story? Where was the cave with the rock rolled across the entrance? Behind that towering alter? Beneath those aspiring candles?" "111 Private Francis Jackson had similar feelings when visiting the Church of the Nativity in Bethlehem. He wrote that "this Church, with its smokestained tapestries and walls, hardly conveyed to the visitor a tumbled-down manger and the crib bed. So we left the Church a little disappointed, as . . . this grandeur I could not associate with the humbleness of the life of Jesus Christ." 112

Still more New Zealanders were disgusted at how commercialised the holy sites were. Many churches and shrines asked visitors for donations, and vendors used popular religious sites as locations to sell their wares. Private Arthur Helm wrote that "everywhere one goes in Jerusalem the holy places are commercialised. To my way of thinking the various creeds and religions would do well to make an effort to set these places above such needs. ... It was noticeable that some of the soldiers were openly scornful when asked for donations." "113 Outside the churches, Private Roger Smith wrote that "the atmosphere of the precincts was anything but reverent: gangs of hawkers, with crosses, rosaries and testaments, were as insistent and clamorous as any Cairo bootblack."114

Some New Zealanders were openly sceptical about the authenticity of religious sites, or the underpinnings of religion itself, but these were a distinct minority. Most at least accepted the religious history these sites represented, even if the sites did not match their expectations. Moreover, those who were sceptical still visited the holy sites alongside their more devout comrades, and still contextualised such places in light of religious history. In this way, religion was unavoidable in the New Zealand experience of Palestine. Though some admired the Holy Land's natural beauty, almost all visited and commented on the famous places of Christianity. All New Zealanders went on a pilgrimage of sorts in the Holy Land, whether they believed in it or not.

\section{The Ancient World}

When New Zealanders went to the Middle East during the war, they went to a place with a long history. Remnants of ancient civilisations were everywhere. The ancient Egyptians and Romans were not just storybook figures in the Middle East, they took on a physical presence through the buildings and artwork they had left behind. As official historian Frazer Norton 
notes, these were things previously only on "the picture postcards . . . seen in bookshops in New Zealand." 115 Now New Zealanders were seeing the real thing.

Roman and ancient Egyptian sites and other ruins and monuments were extremely popular leave destinations for New Zealanders, and accounts of trips to Giza, Baalbek and Luxor pepper wartime correspondence. It should be remembered, as historian Ian McGibbon notes, that "for most of the troops it was their first overseas experience, and sightseeing was an early preoccupation for many." 116 Maadi Camp's proximity to Cairo meant that the pyramids and the Sphinx were the most ubiquitous tourist experiences for New Zealand troops. Like the generation before them in the First World War, New Zealanders had their photo taken astride camels in front of these famous monuments, and such pictures are present in almost every Second World War photo collection.

Many New Zealanders relished the chance to see the pyramids. Private Arthur Helm found his "preconceived idea of the Pyramids was fully borne out when I stood in their gigantic shadow. They are awe inspiring, and one cannot but wonder at the immensity of the project of building them." 117 For Nurse Stephanie Lee, they were "the one place that I have always wanted to see and now I have. ... They are the most interesting and marvellous structures ever built by man." 118 For Laurie Birks, the pyramids "haven't lost the romance and the fascination they had for me when I saw them first . . . though I see them a dozen times a day." 119 Not all New Zealanders were so effusive with their praise. Sapper William Pearson described them as "nothing but heaps of rock surrounded by dust and dirt," and Gunner Thomas Toll thought that "they are well worth seeing once but otherwise they don't interest me much." ${ }^{120}$ Nevertheless, as with holy sites in Palestine, more cynical views did not stop these soldiers from visiting the pyramids anyway. New Zealanders would climb to the top of the pyramids and admire the view over Cairo and the Nile. Private Arthur Helm managed to climb ten pyramids during his time in Egypt - a feat not possible for modern tourists. ${ }^{121}$ 


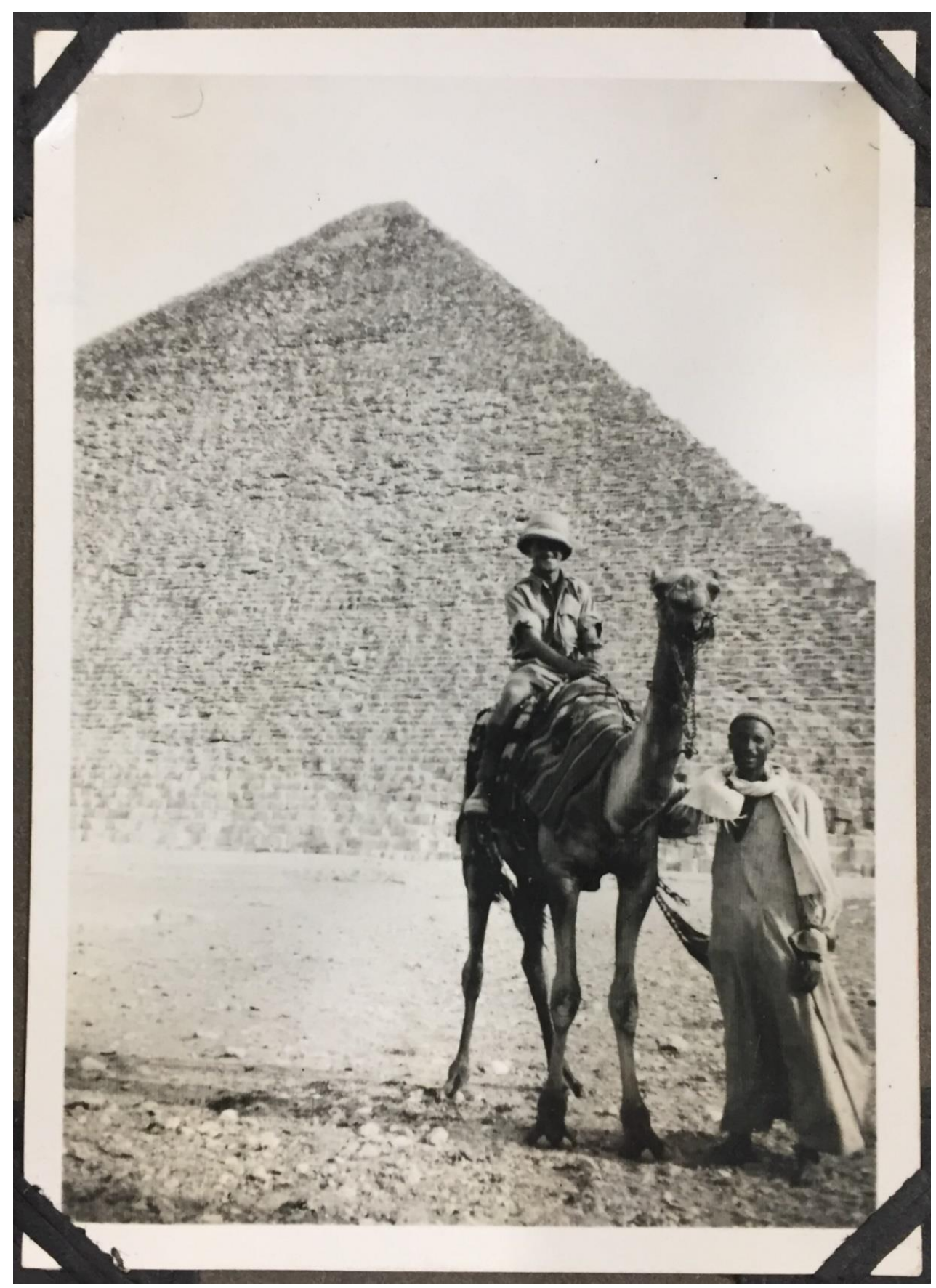

Figure 6. The ubiquitous camel-pyramid photograph, from the album of Private Roy Dalbeth, New Zealand Ordnance Corps. ${ }^{122}$

Roman ruins were also remarked on with interest. When stationed in Syria, the Division was encamped near the ancient town of Baalbek, with its well-preserved Roman temples. Private Sydney Hadley wrote in March 1942 that the Baalbek temples were "magnificent," and he was "astounded by the size of pillars and blocks of rock making the huge buildings." 123 Captain Bruce Robertson was equally "thrilled, and tried to visualise the ancient Romans in their togas wandering among these impressive piles and the still magnificent gardens nearby." "24 Other ruins were encountered at Palmyra, also in Syria, and El Djem in Tunisia. The theatre at Maadi camp was even named El Djem after that ancient Roman amphitheatre. 
Some Roman remains were humbler, and even served a practical function. Private Roger Smith and his comrades, camped near Bardia in Libya, drew their water "from an old Roman cistern, through a small hole in the desert ringed with crumbling masonry." 125 That it was still usable was, according to Smith, "a great tribute to the engineers who had designed and built it." ${ }^{126}$ It was at these wells and other small sites that some New Zealanders began practising amateur archaeology and artefact collecting. For Airman Gerald Craddock it was Roman wells in "our patch of Libyan sand" that spurred his enthusiasm for archaeology. ${ }^{127}$ As he and his bomber crew crisscrossed the Middle East, they attempted to spot ancient sites of interest from the air. ${ }^{128}$ Private Arthur Helm wrote of a comrade called Tuck who "had been bitten rather badly by the archaeology 'bug," who he accompanied on several archaeological trips around Mersah Matruh. ${ }^{129}$ On these trips New Zealanders would collect pieces of tile, pottery or Roman coins as mementoes, bringing a piece of the ancient world with them when they returned home.

New Zealanders were also conscious of the long military lineage in the Middle East. They wrote of the armies that had ranged over the region for thousands of years, placing their experience on a continuum stretching back to the Alexandrian hoplite or Roman legionary. A popular guide book on Palestine reminded New Zealanders that "they come at the end of a long line of soldiers who have spent years of their service in this country. We today are the military successors of Egyptians, Hittites, Syrians, Israelites, Midianites, Philistines, Assyrians, Greeks, Romans, Crusaders, Saracens and Turks; who, one after the other, found cause to bring their forces here." 130 Lieutenant Ian Johnston echoed this idea when travelling along Libya's Mediterranean coast. He wrote of "that historic sea over which the Greeks, the Romans and the Carthaginians had sailed right to the land on which I was standing." "131 In Libya, Private Laurie Birks found it "strange to think that Roman soldiers once trod the same ground as we did," and wondered "if they had to put up with the same as we do, the dust, and the heat in summer and the cold in winter and everything that makes this country so darned inhospitable."132 Bombardier Martyn Uren colourfully sketched the military lineage in a passage on a sixteenth century Spanish castle in Tripoli:

I could not refrain from thinking that this very spot must have seen many guards of varied nationalities. Here . . . long before the Spaniards built the castle, the Carthaginians mounted guard seven centuries before Caesar conquered Britain. Here, again, the Roman centurions must have inspected their men while trumpets blared and banners waved in the fresh sea breeze. This square undoubtedly saw the colourful pomp of Spain, the Eastern splendour of Turkey and the pirates of Barbary. Now a Union Jack flutters from its lofty castle walls. ${ }^{133}$

Thus, engagement with the ancient world went beyond physical ruins and artefacts. New Zealanders imagined their experiences in the context of those who had experienced them in the past. Much in the way that they felt themselves walking in Christ's footsteps in Palestine, they saw themselves marching in the footsteps of the Roman legions throughout the Middle East.

Despite New Zealanders' enthusiasm for history, the ancient world could also form a negative lens through which they viewed the Middle East as a place. Apparent in some New Zealand writing is an undercurrent of regression - an idea that the modern Middle East somehow failed to live up to the standards set by ancient civilisation. This rhetoric is apparent in Private Arthur Helm's account of his travels in Iran and Iraq. Helm's story is truly incredible. A simple private soldier, he chose to travel alone to countries few New Zealanders bothered to visit, rather than spend his leave in Cairo with his comrades. He stayed in local homes and showed a keen interest in indigenous culture and Islamic religion. His reasonable and open-minded attitude to the Middle East stood in stark contrast to the bigoted and parochial views held by many of his 
compatriots. Nevertheless, his writing on Iran and Iraq still evidences the idea that these countries had fallen from the pinnacle of civilisation they represented in ancient times. When travelling through Iraq, he wrote that due to "years of mismanagement under the Turks, and the varied problems that face the country today ... little has been done to return the land to the fertile and prosperous condition that it enjoyed in ages past." 134 Of Baghdad, he wrote that "it contains little of its former splendour and no monuments of its departed glories." 135 And of Iran he wrote that "the vandalism of the Moslems and the Mongols has reduced a once prosperous and flourishing country to a state of poverty."136 This should not detract from the fact that Helm was genuinely fascinated by the Middle East, loved travelling in the region, and even planned to go home after the war via Marco Polo's route through China. ${ }^{137}$ Nevertheless, his writing still reflects a notion that, while the Middle East had a glorious past, its present represented a step backwards. This notion is perhaps best summed up by the caption to a series of photos of the pyramids in Lance Corporal Thomas Goodall's photo album. It simply reads in Latin "gloria transit sic mundi"; "thus passes the glory of the world."138

Much like the Holy Land, the ancient world represented both a physical place and an idea of place. It was certainly somewhere that could be visited in the form of ancient ruins and monuments. However, it also informed notions of history and regression that shaped how New Zealanders viewed the contemporary Middle East. In this way, ancient monuments and civilisations had a currency that belied their millennia-old age.

\section{Conclusion}

For New Zealanders in the Second World War, the Middle East was never a single place. Diversity was the hallmark of their experience in the region. Focussing on the desert, the city, the Holy Land and the ancient world shows that each location presented New Zealanders with something unique. They all represented geographical locations, but they also came with associated ideas of place that were often just as important in framing how New Zealanders viewed the region. Importantly, all four of these place-lenses already existed, in some form, in New Zealanders' imagined Middle East. This meant that when New Zealanders encountered the real place their reactions could be violent and evocative, as their preconceptions were reinforced or subverted. For some, the reality stripped them of all romantic sentiment they held. For others, Like Arthur Helm and Stephanie Lee, Middle Eastern places surpassed expectations and fulfilled lifelong ambitions.

While many certainly had negative impressions of various places, as with much of the discussion of New Zealanders in the Middle East during the World Wars, the negative tends to overshadow the positive, oversimplifying the picture. Historiographically, New Zealanders' reactions to the Middle Eastern landscape have been scant and reductive, emphasising dislike and violent reaction. However, many soldiers found much to appreciate in the history, natural landscapes and polyglot cities of the Middle East. In doing so, they demonstrated how they had imbibed a vernacular orientalism, defined by James Kitchen as "expressing an interest in the history and culture of the non-Western world," These positive reactions were just as much, if not more, a part of New Zealand wartime correspondence as were their negative counterpoints. They show that the New Zealand experience of the Middle East as a place was complex and varied, and cannot be reduced to a one-dimensional picture of "booze and bints." 
${ }^{1}$ Ian Thomas Young Johnston to Family, 8 March 1942, Letters to Family Jan-Jun 1942, Papers
Relating to Service in World War II, MS-Papers-7852-06, 1, Alexander Turnbull Library (ATL).

${ }^{2}$ Robin Kay, Chronology: New Zealand in the War 1939-1946, (Wellington: Historical Publications Branch, Department of Internal Affairs, 1968), 6.

${ }^{3}$ Ian McGibbon, "New Zealand Expeditionary Force," in The Oxford Companion to New Zealand Military History, ed. Ian McGibbon (Auckland: Oxford University Press, 2000), 367.

${ }^{4}$ Alex Hedley and Megan Hutching, Fernleaf Cairo: New Zealanders at Maadi Camp (Auckland:

Harper Collins, 2009), 17.

${ }^{5}$ All dates taken from Kay, Chronology.

${ }^{6}$ Maps and key created by the author.

${ }^{7}$ See particularly the 29 volumes of unit and campaign histories in The Official History of New Zealand in the Second World War, published by the Historical Publications Branch, Department of Internal Affairs, Wellington from 1952 to 1967. Other examples include Ian McGibbon, New Zealand and the Second World War: The People, the Battles and the Legacy (Auckland: Hodder Moa Beckett, 2003); Michael King, New Zealanders at War (Auckland: Penguin, 2003); Glyn Harper, The Battle for North Africa: El Alamein and the Turning Point for World War II (Auckland: Massey University Press, 2017); Matthew Wright, Desert Duel: New Zealand's North African War 1940-1943

(Auckland: Reed Books, 2002); Peter Bates, Dance of War: The Story of the Battle of Egypt (London: Leo Cooper, 1992).

${ }^{8}$ Those exceptions include Hedley and Hutching, Fernleaf Cairo, and parts of John McLeod, Myth and Reality: The New Zealand Soldier in World War II (Auckland: Reed Methuen, 1986).

${ }^{9}$ Ian McGibbon, "Egypt", in The Oxford Companion, ed. McGibbon, 153.

${ }^{10}$ Jock Phillips, A Man's Country: The Image of the Pakeha Male-A History, rev. ed. (Auckland: Penguin Books, 1996), 210-11.

${ }^{11}$ Gerald Rainsborough Craddock, Drink of Nile Water, 1910-1990: Essays and Papers, MSX-2282, 71, ATL.

${ }^{12}$ Richard White, "The Soldier as Tourist: The Australian Experience of the Great War," War \& Society 5, no. 1 (1987): 63-77; Richard White, "Europe and the Six-Bob-a-Day Tourist: the Great War as a Grand Tour, or Getting Civilised," Australian Studies 5 (1991): 122-39; Robin Gerster, "Occidental Tourists: The 'Ugly Australian' in Vietnam War Narrative," in Vietnam Days: Australia and the Impact of Vietnam, ed. Peter Pierce, Jeffrey Grey and Jeff Doyle (Ringwood: Penguin, 1991), 191-236; Bart Ziino, "A Kind of Round Trip: Australian Soldiers and the Tourist Analogy, 19141918," War \& Society 25, no. 2 (2006), 39-52.

${ }^{13}$ Gerster, "Occidental Tourists," 191-92.

${ }^{14}$ Noha Nasser, "A Historiography of Tourism in Cairo: A Spatial Perspective," in Tourism in the Middle East: Continuity, Change and Transformation, ed. Rami Farouk Daher (Clevedon: Channel View Publiations, 2007), 71; John Pemble, The Mediterranean Passion: Victorians and Edwardians in the South (Oxford: Oxford University Press, 1988), 1-3; Richard White, On Holidays: A History of Getting Away in Australia (Melbourne: Pluto Press, 2005), 90; Lynne Withey, Grand Tours and Cooks' Tours: A History of Leisure Travel, 1750-1915 (New York: William Morrow and Company, 1997), 62-63, 224.

${ }^{15}$ James E. Kitchen, “'Khaki Crusaders': Crusading Rhetoric and the British Imperial Soldier During the Egypt and Palestine Campaigns, 1916-18," First World War Studies 1, no. 2 (2010): 156.

${ }^{16}$ Eitan Bar-Yosef, The Holy Land in English Culture 1799-1917: Palestine and the Question of Orientalism (Oxford: Oxford University Press, 2005), 12; Kitchen, "Khaki Crusaders," 152.

${ }^{17}$ Edward W. Said, Orientalism (New York: Vintage Books, 1979), 2.

${ }^{18}$ Bar-Yosef, The Holy Land, 15, 32.

${ }^{19}$ Kitchen, "Khaki Crusaders," 157; A similar popular interest is described in Timothy Mitchell, Colonising Egypt (Berkley: University of California Press, 1991), 1-5.

${ }^{20}$ Hsu-Ming Teo, Desert Passions: Orientalism and Romance Novels (Austin, TX: University of Texas Press, 2012), 67.

${ }^{21}$ Richard Burton, quoted in Kathryn Tidrick, Heart-Beguiling Araby (Cambridge: Cambridge University Press, 1981), 35.

${ }^{22}$ Tidrick, Heart Beguiling Araby, 34. 
${ }^{23}$ Ellen Turner, "E. M. Hull's Camping in the Sahara: Desert Romance Meets Desert Reality," Studies in Travel Writing 19, no. 2 (2015): 131.

${ }^{24}$ Turner, "Hull's Camping," 66.

${ }^{25}$ Tidrick, Heart Beguiling Araby, 48.

${ }^{26}$ James Canton, From Cairo to Baghdad: British Travellers in Arabia (New York: I. B. Tauris, 2011), 69.

${ }^{27}$ Douglas Carruthers, Arabian Adventure: To the Great Nafud in Quest of the Oryx (London: Witherby, 1935), 32.

${ }^{28}$ Frederick Stuart Varnham, Typed Transcript of Diaries Located at MSX 3306 and MSX 3307, transcribed by Nancy Croad, Varnham, Frederick Stuart, 1889-1963: War Diaries, MS-Papers-4380$1,54-55$, ATL.

${ }^{29}$ Varnham, Typed Transcript, 54.

${ }^{30}$ Varnham, Typed Transcript, 55.

${ }^{31}$ Thomas Lawrence Birks to Mrs. R. L. Birks, 16 January 1942, Papers: Letters Jan-June 1942, Letters 39-65, MS-1413, 6-7, Auckland War Memorial Museum (AWMM).

${ }^{32}$ Stephanie Vanoosten to Parents, 11 April 1942, Letters 1941-1944 Vol. 1, Papers Relating to War Service, MS-2002-186, 136, AWMM.

${ }^{33}$ Martyn Uren, Kiwi Saga: Memoirs of a New Zealand Artilleryman (Auckland: Collins, 1943), 37.

${ }^{34}$ Uren, Kiwi Saga, 293-94.

${ }^{35}$ C. Garnett Rands, "The Abomination of Desolation," Photograph Album: Egypt-WWII, 1993.1313.2, Kippenberger Military Archive and Research Library (KMARL).

${ }^{36}$ Sydney Osborn Hadley, Dairy No 2, 24 May 1942, MS-Papers-11780-2, ATL.

${ }^{37}$ Frederick Gordon Mosely to "The Boys of the Right Watch," 7 June 1941, Frederick Gordon Mosely Papers, MS-1692, AWMM.

${ }^{38}$ Bassett Haig Carter, Diary: Bassett H Carter-North Africa \& Italy-WWII, 12 May 1940, 1989.410, KMARL.

${ }^{39}$ Ralph Haig Nicholson, Army Adventures of Gnr R. H. Nicholson, Papers Relating to Service in World War Two, 1 January 1942, MS-Papers-11256-1, 46, ATL.

${ }^{40}$ Walter Young, Wal's Memories of the Western Desert/Transcribed by Elizabeth Young, 7

November 1942, MS-Papers-8825, 26, ATL. This source is a combination of diary entries (as seen here) and later reminiscences.

${ }^{41}$ Young, Wal's Memories, 26.

${ }^{42}$ A. S. Helm, Fights \& Furloughs in the Middle East: A Story of Soldiering and Travel in Libya, Egypt, Palestine, Greece, Crete, Trans-Jordan, Syria, Irak and Iran (Christchurch: Whitcombe \& Tombs, 1944), 16.

${ }^{43}$ Johnston to Family, 19 December 1940, 5.

${ }^{44}$ Rex Dennis Griffith to Gordon and Vera Wadsworth, 30 August 1942, MS-Papers-2252, 13-14, ATL.

${ }^{45}$ Birks to Mrs. R. L. Birks, 13 June 1943, 3.

${ }^{46}$ Young, Wal's Memories, 18.

${ }^{47}$ Craddock, Drink of Nile Water, 37-38.

${ }^{48}$ Birks to Mrs. R. L. Birks, 13 June 1943, 4.

${ }^{49}$ Uren, Kiwi Saga, 251.

${ }^{50}$ FANZ: Compiled and Published by a NZ Field Ambulance (Cairo, 1941), 1999.2198, KMARL.

${ }^{51}$ Helm, Fights and Furloughs, 86.

${ }^{52}$ Uren, Kiwi Saga, 188.

${ }^{53}$ Birks to Mrs. R. L. Birks, 13 April 1942, 4.

${ }^{54}$ Birks to Mrs. R. L. Birks, 16 January 1942, 6.

${ }^{55}$ Harry D. B. Dansey to Mrs. W. P. Dansey, 12 May 1944, Harry D. B. Dansey, Papers, AWMM, MS-873, 8. The first part of this letter is undated. The 12 May date comes from a later continuation of the letter.

${ }^{56}$ Canton, Cairo to Baghdad, 71.

${ }^{57}$ Uren, Kiwi Saga, 35.

${ }^{58}$ Uren, Kiwi Saga, 186. 
${ }^{59}$ John Brown Hood, Palestine Leave, January 1944, Accounts and Papers Relating to Leave in Palestine and Syria, MS-Papers-2159, 1, ATL.

${ }^{60}$ Carter, Diary, 14 February 1940.

${ }^{61}$ J. B. McKinney, The Official History of New Zealand in the Second World War: Medical Units of the 2NZEF in Middle East and Italy (Wellington: Historical Publications Branch, Department of Internal Affairs, 1952), 31.

${ }^{62}$ Desmond Hartley Davis to Mum, Dad and Hazela, 12 January 1943, Letters 1943, MS-2002-75, 8, AWMM.

${ }^{63}$ For an example of this kind of analysis in another context see Roberto Mazza, "Transforming the Holy City: From Communal Clashes to Urban Violence, the Nebi Musa Riots in 1920," in Urban Violence in the Middle East: Changing Cityscapes in the Transition from Empire to Nation State, ed. Ulrike Freitag, Nelida Fuccaro, Nora Lafi and Claudia Ghrawi (New York: Berghahn Books, 2015), 179-94. Mazza shows how the urban environment of Jerusalem, particularly under British occupation after WWI, acted to create particular kinds of behaviour - in this case urban violence.

${ }^{64}$ Nicholson, Army Adventures, 23 October 1941, 35.

${ }^{65}$ Nicholson, Army Adventures, 16 January 1942, 47.

${ }^{66}$ James Barclay, quoted in Megan Hutching, ed., The Desert Road New Zealanders Remember the North African Campaign (Auckland: Harper Collins, 2005), 196.

${ }^{67}$ William John Pearson, Diary: William J Pearson-North Africa \& Italy—WWII, 1989.129, 22 March 1941, KMARL.

${ }^{68}$ Francis Jackson, Passage to Tobruk: The Diary of a Kiwi in the Middle East (Wellington: A. H. and A. W. Reed, 1943), 97.

${ }^{69}$ Reginald Arthur De Grave, The Yellow Rose, War Reminiscences: Tales of Long Ago, MS-99-67, 1, AWMM.

${ }^{70}$ Nicholson, Army Adventures, 8 February 1942, 49-50.

${ }^{71}$ McLeod, Myth and Reality, 132.

${ }^{72}$ McLeod, Myth and Reality, 132. The rate was 47 per 1000 among soldiers compared to 23 per 1000 among civilians.

${ }^{73}$ McLeod, Myth and Reality, 132.

${ }^{74}$ McLeod, Myth and Reality, 132.

${ }^{75}$ Anthony Madden, quoted in Hedley and Hutching, Fernleaf Cairo, 87.

${ }^{76}$ Reginald Arthur De Grave, Cleopatra, War Reminiscences: Tales of Long Ago, MS-99-67, 2, AWMM.

${ }^{77}$ Rosanne Robertson, ed., For the Duration: 2NZEF Officer Bruce Robertson on Active Duty and "In the Bag” (Wellington: Ngaio Press, 2010), 26.

${ }^{78}$ Birks to Mrs. R. L. Birks, 20 March 1942, 5.

${ }^{79}$ Birks to Mrs. R. L. Birks, 20 March 1942, 4.

${ }^{80}$ A. W. Froggatt, "Helwan," Collection: A W Froggatt-WWII, 2014.15.3, KMARL.

${ }^{81}$ Mark Johnston, Anzacs in the Middle East: Australian Soldiers, Their Allies and the Local People in World War II (Melbourne: Cambridge University Press, 2013), 48.

${ }^{82}$ McLeod, Myth and Reality, 126. Johnston also argues this in relation to Australian misbehaviour during war time at various points throughout Anzacs in the Middle East.

${ }^{83}$ Uren, Kiwi Saga, 42-43.

${ }^{84}$ Uren, Kiwi Saga, 145-46.

${ }^{85}$ Young, Wal's Memories, p. 17; B. T. J. J., "The New Zealander on Leave," in Bab el Look, ed. Lt. E. H. Halstead (Cairo: Societe Orientale de Publicite, 1941). There are no page numbers in this magazine.

${ }^{86}$ Davis to Mum, Dad and Hazela, 12 January 1943, 4.

${ }^{87}$ Thomas James Toll to Ron Hill, 9 October 1943, Letter: Thomas J Toll-Middle East WWII, 2007.542, 4, KMARL.

${ }^{88}$ Arthur Sutherland Moore, Diary: North Africa \& Italy WWII, 22 March 1941, 2005.736, 7, KMARL.

${ }^{89}$ Hood, Palestine Leave, 6; Robertson, ed., For the Duration, 11.

${ }^{90}$ Helm, Fights and Furloughs, 217; George Newton, Account of Journey from Cairo to Tehran, 12 April 1942; 9 April 1942, MS-Papers-8745, ATL. 
${ }^{91}$ Hadley, Diary, 1 March 1942.

${ }^{92}$ Newton, Account of Journey, 9 April 1942.

${ }^{93}$ Hood, Palestine Leave, 13.

${ }^{94}$ Vanoosten to Parents, 2 July 1942, 201.

${ }^{95}$ Helm, Fights and Furloughs, 183.

${ }^{96}$ Frederick Keith Robbie to Doris Robbin, 7 June 1942, Letters; Middle East-WWII, 2004.209, 1, KMARL.

${ }^{97}$ Johnston to Family, 8 March 1942, 4; Helm, Fights and Furloughs, 46; Harold Loftus, Diary:

Greece, Crete \& North Africa-WWII, 5 March 1942, 1996.1220, KMARL; F. R. L. P.,

"Impressions," Kiwit: Unit Magazine of 2 NZ General Hospital 1, no. 2 (May 1942): 42; Craddock, Drink of Nile Water, 40.

${ }^{98}$ Stephanie Stidham Rogers, Inventing the Holy Land: American Protestant Pilgrimage to Palestine, 1865-1941 (Lanham, MD: Lexington Books, 2011), 2; Brian Yothers, The Romance of the Holy Land in American Travel Writing, 1790-1876 (Aldershot: Ashgate, 2007), 5.

${ }^{99}$ Allen Davidson, Christianity in Aotearoa: A History of Church and Society in New Zealand, 2nd ed. (Wellington: New Zealand Education for Ministry, 1997), 106.

${ }^{100}$ Christine Weir, "Deeply Interested in These Children Whom You Have Not Seen: The Protestant

Sunday School View of the Pacific, 1900-1940," The Journal of Pacific History 48, no. 1 (2013): 44.

${ }^{101}$ Weir, "Deeply Interested," 45.

${ }^{102}$ Geoffrey M. R. Harworth, Marching as to War? The Anglican Church in New Zealand During

World War II, (Christchurch: Wily Publications, 2008), 51.

${ }^{103}$ Harworth, Marching as to War, 67.

${ }^{104}$ Jackson, Passage to Tobruk, 82.

${ }^{105}$ Ian Denis Smith to Mary Dympna, 7 June 1942, Letter: Egypt-WWII, 2005.806, 3, KMARL.

${ }^{106}$ Helm, Fights and Furloughs, 59.

${ }^{107}$ Kerrie Handasyde, "Holy Land Tourism: A Horseback Ride from Public Theology to Private

Faith", Melbourne Historical Journal 43, no. 1 (January 2015): 101.

${ }^{108}$ Yothers, Romance of the Holy Land, 1.

${ }^{109}$ Kitchen makes a similar comment about British soldiers in the First World War; see Kitchen,

"Khaki Crusaders," 149.

${ }^{110}$ Roger Smith, Up the Blue: A Kiwi Private's View of the Second World War (Wellington: Ngaio Press, 2000), 23.

${ }^{111}$ Smith, Up the Blue, 23.

112 Jackson, Passage to Tobruk, 84.

${ }^{113}$ Helm, Fights and Furloughs, 56.

${ }^{114}$ Smith, Up the Blue, 22.

${ }^{115}$ Frazer D. Norton, The Official History of New Zealand in the Second World War: 26 Battalion (Wellington: Historical Publications Branch, Department of Internal Affairs, 1952), 9.

${ }^{116}$ McGibbon, "Egypt," 153.

${ }^{117}$ Helm, Fight and Furloughs, 24-25.

${ }^{118}$ Vanoosten to Parents, 1 March 1942, 90.

119 Thomas Lawrence Birks to Mrs. R. L. Birks, 4 October 1942, Papers: Letters July-Dec 1942, Letters 66-92, MS-1413, 10, AWMM.

${ }^{120}$ Pearson, Diary, 6 May 1941; Toll to Ron Hill, 9 October 1943, 4.

${ }^{121}$ Helm, Fights and Furloughs, 28.

${ }^{122}$ Roy Leonard Dalbeth, "Don at Big Pyramid," Photograph Album: England, Egypt, Greece \& Italy-WWII, 2004.420, KMARL.

${ }^{123}$ Hadley, Diary, 6 March 1942.

${ }^{124}$ Robertson, ed., For the Duration, 33.

${ }^{125}$ Smith, Up the Blue, 28.

${ }^{126}$ Smith, Up the Blue, 28.

${ }^{127}$ Craddock, Drink of Nile Water, 40.

${ }^{128}$ Craddock, Drink of Nile Water, 43.

${ }^{129}$ Helm, Fights and Furloughs, 15. 
${ }^{130}$ H. G. Williamson, Palestine Past and Present, 2nd ed. (1938), Collection: Alan Hardie NapierWWII, 2013.14.1, KMARL.

${ }^{131}$ Johnston to Family, 6 December 1940, 3.

${ }^{132}$ Birks to Mrs. R. L. Birks, 16 January 1942.

${ }^{133}$ Uren, Kiwi Saga, 317.

${ }^{134}$ Helm, Fights and Furloughs, 211.

${ }^{135}$ Helm, Fights and Furloughs, 215.

${ }^{136}$ Helm, Fights and Furloughs, 280.

${ }^{137}$ Helm, Fights and Furloughs, 275.

${ }^{138}$ Thomas Arnold Goodall, Photograph Album: Egypt, Greece \& Crete-WWII, 2000.723, KMARL. 